\title{
EFFECT OF ORGANIC AND MINERAL FERTILIZERS ON GROWTH AND YIELD OF COCOYAM (COLOCASIA ESCULENTA (L.) SCHOTT)
}

\author{
UWAH D.F.*1, UDOH A.U. ${ }^{2}$, IWO G.A. ${ }^{1}$ \\ 'Department of Crop Science, University of Calabar, P.M.B, 1115, Calabar, Nigeria \\ 2Department of Agronomy, Michael Okpara University of Agriculture, Umudike, Nigeria, \\ *Corresponding author. E-mail: dfu55@yahoo.com
}

Received: August 10, 2010; Accepted: October 15, 2010

\begin{abstract}
The response of cocoyam (Colocasia esuclenta (L.) Schott) to various rates of poultry manure (PM) and potassium(K) fertilizer was studied under field conditions in 2006 and 2007 growing seasons at Uyo, a humid forest agroecology of south eastern Nigeria. Treatment combinations comprising of four rates each of PM $(0,5,10$ and $15 \mathrm{t} / \mathrm{ha})$ and $\mathrm{K}(0,40,80$ and $120 \mathrm{~kg} \mathrm{~K} / \mathrm{ha})$ were factorized and fitted into a randomized complete block design with three replicates. Application of PM and $\mathrm{K}$ at the highest rates produced significantly taller plants with higher leaf area index, shoot dry matter, corms and cormels number, compared with other treatments in both years. Weight of corms and cormels and total yield (t/ha) were however, optimized at 10t/ha and $80 \mathrm{~kg} \mathrm{~K} / \mathrm{ha}$ rate. Averaged over the two years, increases in PM and $\mathrm{K}$ rates from zero to $15 \mathrm{t} / \mathrm{ha}$ and $120 \mathrm{~kg} \mathrm{~K} / \mathrm{ha}$, increased the shoot dry matter by $51 \%$ and $29 \%$, and the number of corms and cormels by $40 \%$ and $34 \%$, respectively. Weight of corms and cormels and total yield obtained in the two years at 10t/ha and 15t/ha PM, and $80 \mathrm{~kg} \mathrm{~K} / \mathrm{ha}$ and 120 $\mathrm{kg} \mathrm{K} /$ ha were statistically similar except in 2007 where the corms and cormels weight peaked at 15t/ha PM rate. Poultry manure at 15t/ha in combination with either $80 \mathrm{~kg} \mathrm{~K} / \mathrm{ha}$ or $120 \mathrm{~kg} \mathrm{~K} / \mathrm{ha}$ out-yielded other treatments in terms of corms and cormels weight and total yield in the two years of trial.
\end{abstract}

Keywords- Cocoyam, cormels, corms, potassium fertilizer, poultry manure, rates, shoot dry matter, yield.

\section{Introduction}

Cocoyam (Colocasia esculenta (L.) Schott.) a member of the Araceae family is a subsistence and emergency food source in many parts of the world, but a major staple food crop in Nigeria, South Pacific islands and some parts of Asia [1]. The corms and cormels are eaten in the same way as yam (Dioscorea spp) and sweet potato (Ipomoea batatas), boiled, fried, baked and roasted. In West Africa, the boiled cocoyam is sometimes pounded to produce a paste similar to pounded yam and eaten in the same manner. The cormels are grated and used alone or mixed with grated water yam (Dioscorea alata) to prepare a rich popular Nigeria diet called ekpang nkukwo. Cocoyams are the cheapest and most handy carbohydrate source of meals for diabetics, convalescents and most gastrointestinal disorder patients and a good carbohydrate base for infact foods on account of their small-sized starch grains which are easily digested compared to those of yam, cassava (Manilot spp) or sweet potato $[1,2]$. The young leaves and petioles which contain more protein than the corms in addition to vitamin $\mathrm{A}$ and $C$ and minerals are used as human food, while the corms, cormels and leaves after curing can also be used as animal feed [3]. In the rain forest agroecology of south eastern Nigeria, intensive cropping has become more common and the primary function of soil productivity and fertility restoration is becoming less effective [4]. Bush fallow which had been an efficient, balanced and sustainable system for soil productivity and fertility restoration in the past is presently unsustainable due to high population pressure and other human activities which have resulted in reduced fallow period [5]. A major constraint to intensive production of cocoyam in this agroecology is the low level of inherent fertility of the acid sandy soils. Due to the porous nature of the soils, their low organic matter, $\mathrm{pH}$ and clay contents; native soil N, K and $\mathrm{Ca}$ are equally very low. The implication is that with the usually high rainfall experienced in this zone, the application of inorganic fertilizers is accompanied by a high rate of leaching losses [6]. To ameliorate these problems, complementary use of organic manures and mineral fertilizers which has proved to be a sound soil fertility management strategy in many countries of the world is advocated [7]. Apart from enhancing crop yield, the practice has a greater beneficial residual effect than can be derived from the use of either inorganic fertilizer or organic manure when applied alone [8, 6, 9, 10]. Nutrient use efficiency has also been reported to increase through the combination of poultry manure and mineral fertilizer $[11,12]$. Cocoyam being a root crop has a high requirement for potassium as yam and cassava $[13,14,3,1]$. The $K$ content of poultry 
manure is usually very high depending on the animal type, feed ration, storage and handling practice which makes it very suitable for root crops. Surveys in Nigeria and elsewhere revealed inconsistencies in the amount of $\mathrm{K}$ for optimum performance of cocoyam due mainly to differences in soil types and soil $K$ status $[15,16,17]$. Information on the effect of poultry manure on this crop under field conditions in Nigeria is scanty. The objective of this study therefore was to determine the effect of poultry manure (PM) and potassium (K) fertilizer on agronomic performance of cocoyam in south eastern Nigerian environment.

\section{Materials and methods}

Experiments were conducted for two years during the rainy seasons of 2006 and 2007 at the National Cereal Research Institute out-station at Owot Uta, Uyo, south eastern rainforest zone of Nigeria (Lat $4^{\circ} 30^{\prime}$ and $5^{\circ} 30^{\prime} \mathrm{N}$, Long. $7^{\circ} 5^{\prime}$ and $8^{\circ} 20^{\prime} \mathrm{E}$; $100 \mathrm{~m}$ altitude). Uyo has a mean annual rainfall of about $2500 \mathrm{~mm}$ during the rainy season which is from March to November. Mean relative humidity of $78 \%$, mean annual minimum and maximum temperatures of $22.5^{\circ}{ }^{\circ} \mathrm{C}$ and $30.7^{\circ}{ }^{\circ} \mathrm{C}$. The soil is acidic and belongs to broad soil classification group Alfisol, with well drained coastal plain sands of Benin formation, low in organic matter, nitrogen, potassium and other nutrients [18]. The physicochemical analyses of the soil at experimental sites are summarized in Table 1. The experiments evaluated the effect of four rates of poultry manure (PM) $(0,5,10$ and 15t/ha), and four rates of potassium fertilizer $(\mathrm{K})(0,40,80$ and $120 \mathrm{~kg} \mathrm{~K} / \mathrm{ha})$ on the performance of cocoyam (Colocasia esulenta (L.) Schott). The treatment combinations were factorized and fitted into a randomized complete block design with three replications. A fresh site which had been on fallow for three years was used each year. Poultry manure was obtained from the broiler pens of the Teaching and Research Farm of the University of Uyo, with the birds fed with a finisher diet. The bedding materials consisted mainly of saw dust. The potassium fertilizer source was muriate of potash $(50 \% \mathrm{~K})$ Composite samples of the poultry manures were air dried, crushed, sieved and analyzed for chemical properties [19]. A relevant chemical analysis of the manure is summarized in Table 2. Soil samples were collected from the sites at depths of $0-30 \mathrm{~cm}$ prior to manure and fertilizer applications and analyzed for physicochemical properties using procedures described by [19] (Table 1). The sites were cleared of vegetation with machetes, ploughed and ridged using a tractor and marked out into blocks of 16 plots each. Gross plot size was $7 \mathrm{~m} \times 4 \mathrm{~m}$ and the net plot from which growth and yield parameters were measured, was $3 \mathrm{~m} \times 2 \mathrm{~m}$. Plots were separated by a path of $1 \mathrm{~m}$ while blocks were kept at a distance of $1.5 \mathrm{~m}$ between them. The planting material consisting of cocoyam cormels of mean weight $72 \mathrm{~g}$ obtained from Akwa Ibom State Agricultural Development Programme (AKADEP) Uyo, were planted one per stand at $15 \mathrm{~cm}$ depth on the crest of the ridges at a spacing of $1 \mathrm{~m} \times 1 \mathrm{~m}$, in early March in both years. Supplying was done a month after planting to maintain a uniform rate of one plant per stand. The poultry manure was incorporated into the soil of the replicated plots in a single dose as per the various treatments and allowed to decompose for two weeks before planting. Potassium fertilizer was side-dressed about $8 \mathrm{~cm}$ deep and $15-20 \mathrm{~cm}$ away from the plants and covered with soil in a single dose four weeks after planting (WAP). Weeding was done manually using native hoe at 4,8 and 12 weeks after planting. Harvesting was done in November of both years, 8 months after planting by carefully digging out corms and cormels with native hoe when the leaves had dried up. From the six plants in the net plot areas, the corms and cormels were separated before the yield and yield components were determined. Parameters measured were plant height, leaf area index, shoot dry matter, number of corms and cormels per plant, weight of corms and cormels per plant and corms and cormels yields (t/ha). Leaf area index was determined using the method of [20]. Data were subjected to analysis of variance [21]. Treatment means were compared using Fisher's Least Significant Difference (LSD), [22].

\section{Results}

The chemical characteristics of the experimental soils indicated low nitrogen $(\mathrm{N})$ and potassium $(\mathrm{K})$ but high phosphorus $(\mathrm{P})$ status (Table 1). Organic carbon content and $\mathrm{pH}$ were lower in 2006 than 2007 cropping season. The chemical composition of poultry manures (PM) used, differed substantially (Table 2). The PM in 2007 was higher in N, P, K and Calcium (Ca) contents by $20 \%, 34 \%, 0.7 \%$ and $105 \%$ respectively, than in 2006.

Table 3 shows the effects of PM and $K$ fertilizer on growth parameters of cocoyam. The highest rates of $\mathrm{PM}$ and $\mathrm{K}$ fertilizer produced the tallest plants in both years. The leaf area index was significantly increased $(P<0.05)$ by increasing application rates of $P M$ and $K$ in the two years. The interactions between $\mathrm{PM}$ and $\mathrm{K}$ was significant for plant height and leaf area index. The combination of 15t/ha PM and $120 \mathrm{~kg} \mathrm{~K} /$ ha produced taller plants in 2006 while in 2007, same result was obtained but with the combinations of either 10t/ha or 15t/ha PM and 120 $\mathrm{kg} \mathrm{K} / \mathrm{ha}$. The leaf are index peaked with the combinations of either 10t/ha or 15t/ha PM and 120 $\mathrm{kg} \mathrm{K} / \mathrm{ha}$ in 2006, while the highest rates of PM and $\mathrm{K}$ in combination maximized leaf area index in 2007. Shoot dry matter and number of corms and cormels per plant increased with each incremental application of PM and $\mathrm{K}$ up to the highest rates in both years (Table 4). Averaged over the two years, 
increases in PM rates from 0 to 15t/ha, increased the shoot dry matter by $51 \%$ and the number of corms and cormels by 40 percent. Similar trend was observed with $\mathrm{K}$ on these parameters although the values obtained were lower. The shoot dry matter increase obtained on average over the two years was $29 \%$, while that of number of corms and cormels was $34 \%$ compared with the control. PM $x$ $K$ interaction was significant $(P<0.05)$ on shoot dry matter and number of corms and cormels. Shoot dry matter and number of corms and cormels across the years were maximized with the combination of $\mathrm{PM}$ at $15 \mathrm{t} / \mathrm{ha}$ and $\mathrm{K}$ at $120 \mathrm{~kg} / \mathrm{ha}$ (Table 4). Corms and cormels weight significantly increased as application of PM was increased to 10t/ha but not further in 2006 and up to 15t/ha in 2007 (Table 5). Each incremental rate of $\mathrm{K}$ increased the corms and cormels weight only up to the $80 \mathrm{~kg} / \mathrm{ha}$ rate in both years. Corms and cormels yields (t/ha) increased consistently with increasing rates of PM from 0 to $15 \mathrm{t} / \mathrm{ha}$ rate in the two years. The difference in yield increase between 10t/ha and 15t/ha was however not statistically significant. Averaged over the two years, increases in PM rates from 0 to 5 t/ha, resulted in $31 \%$ increase in corms and cormels yield; a further increase to 10t/ha, further increased yield substantially by $67 \%$, while a further increase to $15 \mathrm{t} / \mathrm{ha}$ produced a yield increase of only 27 percent. Similar results were observed with $\mathrm{K}$ application in which the $120 \mathrm{~kg} / \mathrm{ha}$ rate gave the best value for corms and cormels yield, although this was not significantly different from the yield obtained at $80 \mathrm{~kg} \mathrm{~K} /$ ha rate. The application of 40 , 80 and $120 \mathrm{~kg} \mathrm{~K} / \mathrm{ha}$ gave an aggregate total corms and cormels yield of $26 \%, 83 \%$ and $102 \%$ respectively, over zero application. The PM x K interaction was significant for both corms and cormels weight and yield in the two years of trial. In both years, PM at 15t/ha in combination with either $80 \mathrm{~kg} \mathrm{~K} / \mathrm{ha}$ or $120 \mathrm{~kg} \mathrm{~K} / \mathrm{ha}$ maximized corms and cormels weight and yield.

\section{Discussion}

The growth and yield performance of the crop appeared better in the 2007 trial than 2006 probably due to the differential nutrient status of each site. The chemical composition of the sites indicated that the 2007 site had a more favourable $\mathrm{pH}$, higher organic carbon, $\mathrm{N}$ and $\mathrm{K}$ contents than that of 2006 which could have accounted for the superior crop performance in 2007 (Table 1). The mineral compositions of the PM used in both years differed which may further explain the differential response of the crop to the applied manure. The N, P, K. and Ca contents of PM used in 2007 was higher than that of the 2006 cropping season (Table 2). The overall results indicated that tallest plants and maximum leaf area index occurred at the highest rates of $\mathrm{PM}$ and $\mathrm{K}$. Superior trend in growth and leaf area index has been reported by other workers with high rates of organic and inorganic fertilizer application [23, 24]. Average maximum shoot dry matter production in 2006 and 2007 were $55.7 \mathrm{~g} /$ plant and $58.0 \mathrm{~g} /$ plant respectively, obtained with $\mathrm{PM}$ at $15 \mathrm{t} / \mathrm{ha}$ rate, while the figures for $\mathrm{K}$ for the same periods were $52.3 \mathrm{~g} /$ plant and $54.6 \mathrm{~g} / \mathrm{plant}$ at $120 \mathrm{~kg} \mathrm{~K} / \mathrm{ha}$. [25] obtained similar results on shoot dry matter in cocoyam with high rates of organic manures. Corms and cormels numbers and total yield ( $t / h a)$ were optimized at the highest rates of both manures though the values recorded for these parameters at 10/ha and 15t/ha PM or $80 \mathrm{~kg} \mathrm{~K} / \mathrm{ha}$ and $120 \mathrm{~kg} \mathrm{~K} /$ ha were statistically similar in the two years. Decreasing trends were observed with values obtained for these parameters with increasing rates of the manures. This suggests therefore that for cocoyam production in this agroecology, increasing $\mathrm{PM}$ and $\mathrm{K}$ rates above 10t/ha and $80 \mathrm{~kg} \mathrm{~K} / \mathrm{ha}$ respectively, might not produce significant yield increases. This result confirms to that of earlier trial by [16] which indicated that cocoyam requires high $\mathrm{K}$ levels with the best results obtained at between 50 and $80 \mathrm{~kg}$ $\mathrm{K} /$ ha rates depending on the soil types. Abundant $\mathrm{K}$ supply has been reported to favour primary process of photosynthesis and ATP production as well as promote carbon dioxide assimilation and the synthesis and translocation of carbohydrate from the leaves to the tubers of potatoes, yam or cassava $[15,26]$ This may explain the high corms and cormels yield obtained in crops well supplied with $\mathrm{K}$. The results also depicted better crop performance in all parameters measured with PM than $\mathrm{K}$ fertilizer. This could be attributed to the show release of nutrients from decomposing organic manure with reduced leaching losses of nutrients throughout the growth period and the fact that PM has a favourable influence on soil $\mathrm{pH}$ [27]. The interaction between $\mathrm{PM}$ and $\mathrm{K}$ indicated that the combination of $\mathrm{PM}$ at $15 \mathrm{t} / \mathrm{ha}$ with either $80 \mathrm{~kg} \mathrm{~K} / \mathrm{ha}$ or $120 \mathrm{~kg} \mathrm{~K} / \mathrm{ha}$ maximized corms and cormels weight and yield in the two years of trial. The observed increases in yield attributes due to PM $\times \mathrm{K}$ interaction are attributable to the complementary action between the two manures. [28] asserted that when organic manure is applied together with mineral fertilizers, the latter aids the decomposition of the former. [29, 7, 12] also observed that the use of PM increased the efficiency of inorganic fertilizer probably by serving as a liming material and providing secondary and micronutrients not present in the inorganic fertilizers. This may therefore explain the significant response of these yield attributes when both PM and $\mathrm{K}$ were applied together than separately. The superior corms and cormels yield obtained at 15t/ha PM with either 80 $\mathrm{kg} \mathrm{K} / \mathrm{ha}$ and $120 \mathrm{~kg} \mathrm{~K} / \mathrm{ha}$, confirms reports by [8, 30] that high and sustained crop yield can be obtained with judicious and balanced inorganic fertilization combined with organic manures. 


\section{Conclusion}

The study revealed that both poultry manure and $\mathrm{K}$ promote growth and yield of cocoyam. From the findings therefore, adoption of the combination of 15t/ha PM and $80 \mathrm{~kg} \mathrm{K/ha} \mathrm{could} \mathrm{optimize} \mathrm{yield} \mathrm{in}$ this agroecology for cocoyam production.

\section{References}

[1] IFA (1992) World fertilizer Use Manual. Publication of International Fertilizer Industry Association, Paris pp 148-160.

[2] Som, D. (2007) Handbook of Horticulture, Indian Council of Agricultural Research, New Delhi, pp 507-508.

[3] Onwueme I. C. and Sinha T. O. (1991) Field crop production in Tropical Africa, CTA Ede, The Netherlands, pp 276-288.

[4] Okigbo B. N. (1982) In: Proceeding of the International Workshop on shifting cultivation, FAO, Rome, pp18-36.

[5] Steiner K. G. (1991) In: Mokwunye A. U. (ed.) Alleviating soil fertility constraints to increased crop production in West Africa pp69-91.

[6] Agboola A. A. (1998) Soil fertility in Ajibode, Ibadan, Department of Agronomy, Uni. of Ibadan Nigeria, Memo., $31 \mathrm{pp}$.

[7] Lombin L.G., Adepetu J. A. and Ayotade k. A. (1994) In: Organic fertilizer in the Nigerian Agriculture: Present and Future. FPDD Abuja, Nigeria, pp146-162.

[8] Kang B. T. and Balasubramanian V. (1990) In: Transactions of XIV International Soil Science Society (ISSS) congress, Kyoto, Japan, 350pp.

[9] Aliyu L. (2000) Biological Agric. \& Hort. 18:29-36.

[10] Eneji A. E., Honna T., Yamamoto S. and Masuda T. (2003) J. of Plant Nutr. 26 (8): 1595-1604.

[11] Murwira H. K. and Kirchmann H. (1993) Soil organic matter dynamics and sustainability of tropical agriculture pp189198.

[12] Ayoola O. T. and Adeniyan O. N. (2000) African J. Biotech., 5:1386-1392.

[13] Obigbesan G. O; Agboola A. A. and Fayemi A. A. (1976) Proc. 4th symp. Inter. Soc. Tropical Root Crops, pp104-107.

[14] Kay D. E. (1987) Tropical Development and Research Institute, 380pp.

[15] Obigbesan G. O. (1980) In: Potassium Workshop, Oct. 1980, IITA, Ibadan, Nigeria.

[16] Ohiri A. C., Ogbonnaya J. C., Enyinnaya A. M., Ojinaka, T. L., Chukwu G. O. (1988) Annual Report, NRCRI, Umudike pp75-77.
[17] Ohiri A. C., Nwokocha H. N., Okwuowulu P. A. and Chukwu G. O. (1996) Final report submitted to NAFCON (Nig.) Ltd. NRCRI, 54pp.

[18] Peters S. W., Usoro E. J., Udo E. J., Obot U. W. and Okpon S. N. (Eds) (1989) A technical report of task force on soils and land survey Akwa Ibom State 603pp.

[19] IITA (1982) Selected methods of soil and plant analysis. International Institute of Tropical Agriculture Manual Series No. 7 Ibadan. Nigeria.

[20] Agueguia A. (1993) Agronomy and Crop Science 171:138-141.

[21] Snedecor C. W. and Cochran W. G. (1967) Statistical methods, lowa State Uni. Press, USA; 507pp.

[22] Gomez K. A. and Gomez A. A. (1984) Statistical Procedures for Agricultural Research (2nd ed.) John Wiley and Sons, New York 680pp.

[23] Goenaga R. (1995) Ann. Bot. 76:330-341

[24] Obasi M. N., Mbanaso E. N. A. and Ano A. O. (2005) Annual Report NRCRI, Umudike, pp159-166.

[25] Miyasaka S. C., Hollyer J. R. and Kodani L. S. (2001) Field Crops Res. 71: 101112.

[26] Mengel K. and Kirkby E. A. (2001) Principles of plant nutrition (5th ed.) Kluwer Academic Publishers, The Netherlands pp317-320.

[27] Cooke G. W. (1982) ELBS, London, pp 94-110.

[28] Mokwunye U. (1980) In: Organic cycling in Africa soils Bull. FAO, Rome, No. 43:192-200.

[29] Lombin L. G. and Abdullahhi K. A. (1978) Samaru Misc. Paper 55, 12pp.

[30] IITA (1990) Cassava in Tropical Africa. A Reference Manual. International Institute of Tropical Agriculture, Ibadan Nigeria, $176 \mathrm{pp}$.

\section{End note}

Drs. A.U. Udoh, G. A. Iwo assisted immensely in the field in data collection and analysis of the data. They also assisted financially in the area of publication fee. 
Table 1- Physico-chemical properties of experimental soils during 2006 and 2007 rainy season at Uyo, Nigeria

\begin{tabular}{|l|l|l|}
\hline & Year \\
\hline Composition & 2006 & 2007 \\
\hline Physical composition (g/kg) & & \\
\hline Sand & 894.6 & 908.0 \\
\hline Silt & 40.0 & 42.0 \\
\hline Clay & 65.4 & 50.0 \\
\hline Textural class & Sandy loam & Sandy loam \\
\hline Chemical characteristics & & \\
\hline pH in $\left(\mathrm{H}_{2} \mathrm{O}\right)(1: 2.5)$ & 5.30 & 6.50 \\
\hline $\mathrm{pH}$ in $0.01 \mathrm{~m} \mathrm{C}_{2} \mathrm{Cl}_{2}(1: 2.5)$ & 5.00 & 5.60 \\
\hline Organic carbon $(\%)$ & 1.52 & 3.98 \\
\hline Total Nitrogen $(\%)$ & 0.04 & 0.11 \\
\hline Available Phosphorus $(\mathrm{mg} / \mathrm{kg})$ & 49.99 & 38.99 \\
\hline Exchangeable bases $(\mathrm{cmol} / \mathrm{kg})$ & & \\
\hline Ca & 7.20 & 3.46 \\
\hline Mg & 2.03 & 1.29 \\
\hline $\mathrm{K}$ & 0.10 & 0.15 \\
\hline $\mathrm{Na}$ & 0.04 & 0.06 \\
\hline Exchangeable Acidity $(\mathrm{cmol} / \mathrm{kg})$ & 1.80 & 2.93 \\
\hline ECEC $(\mathrm{cmol} / \mathrm{kg})$ & 11.17 & 7.89 \\
\hline Base Saturation $(\mathrm{g} / \mathrm{kg})$ & 838.9 & 628.6 \\
\hline
\end{tabular}

Table 2: Chemical properties of poultry manure

\begin{tabular}{|l|l|l|l|l|l|l|l|l|l|l|}
\hline Poultry Manure & $\mathrm{N}$ & $\mathrm{P}$ & $\mathrm{K}$ & $\mathrm{Mg}$ & $\mathrm{Ca}$ & $\mathrm{Na}$ & $\mathrm{Mn}$ & $\mathrm{Cu}$ & $\mathrm{Fe}$ & $\mathrm{Zn}$ \\
\hline & $(\%)$ & $(\mathrm{mg} / \mathrm{kg})$ & $(\mathrm{cmol} / \mathrm{kg})$ & \multicolumn{7}{|l|}{} \\
\hline 2006 & 2.66 & 2620 & 4395 & 1846 & 2243 & 891.0 & 227.9 & 19.0 & 21.8 & 183.5 \\
\hline 2007 & 3.20 & 3500 & 4752 & 1760 & 4600 & 821.0 & 214.2 & 16.8 & 19.6 & 164.6 \\
\hline
\end{tabular}

Table 3-Plant height (cm) at 32 WAP and leaf area index (LAI) at 20 WAP of cocoyam as affected by poultry manure and potassium fertilizer in Uyo, Nigeria.

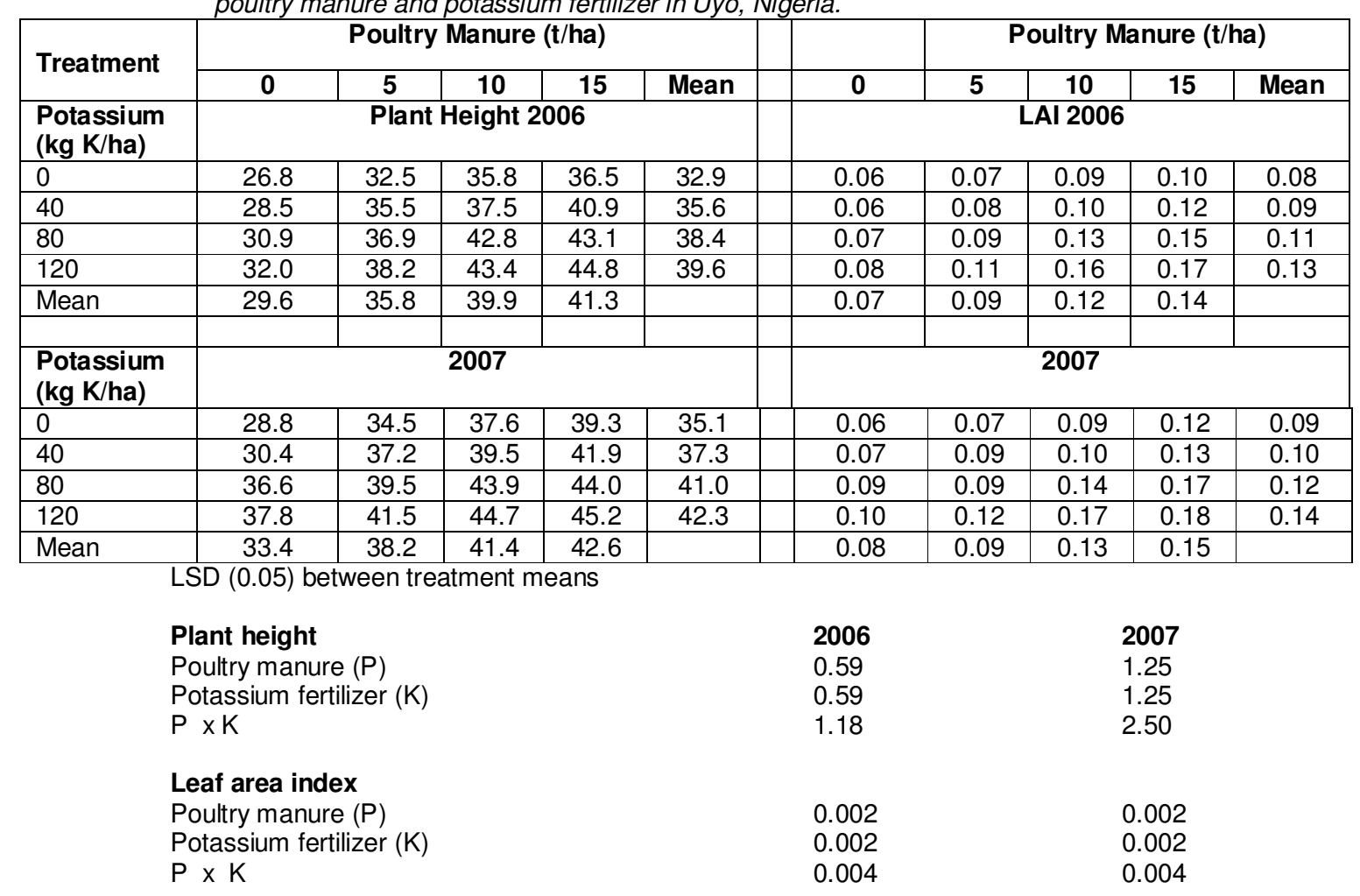


Table 4- Shoot dry matter (g/plant) at 32 WAP and number of corms/cormels of cocoyam as affected by poultry manure and potassium fertilizer in Uyo, Nigeria.

\begin{tabular}{|c|c|c|c|c|c|c|c|c|c|c|}
\hline \multirow{2}{*}{ Treatment } & \multicolumn{5}{|c|}{ Poultry Manure (t/ha) } & & \multicolumn{4}{|c|}{ Poultry Manure (t/ha) } \\
\hline & 0 & 5 & 10 & 15 & Mean & 0 & 5 & 10 & 15 & Mean \\
\hline $\begin{array}{l}\text { Potassium } \\
\text { (kg K/ha) }\end{array}$ & \multicolumn{5}{|c|}{ Shoot dry matter 2006} & \multicolumn{5}{|c|}{ No. of corms/cormels 2006} \\
\hline 0 & 34.0 & 37.4 & 44.0 & 47.2 & 40.7 & 7.0 & 7.4 & 7.9 & 8.5 & 7.7 \\
\hline 40 & 36.0 & 39.2 & 49.8 & 53.4 & 44.6 & 7.3 & 7.9 & 8.8 & 10.0 & 8.5 \\
\hline 80 & 36.6 & 42.8 & 56.8 & 59.6 & 49.0 & 7.8 & 8.8 & 9.9 & 11.4 & 9.5 \\
\hline 120 & 39.6 & 46.6 & 60.6 & 62.4 & 52.3 & 8.4 & 9.4 & 11.4 & 12.7 & 10.5 \\
\hline Mean & 36.6 & 41.5 & 52.8 & 55.7 & & 7.6 & 8.4 & 9.5 & 10.7 & \\
\hline $\begin{array}{l}\text { Potassium } \\
\text { (kg K/ha) }\end{array}$ & \multicolumn{5}{|c|}{2007} & \multicolumn{5}{|c|}{2007} \\
\hline 0 & 34.6 & 39.4 & 45.0 & 50.4 & 42.4 & 7.2 & 8.0 & 8.5 & 9.0 & 8.2 \\
\hline 40 & 37.8 & 42.2 & 52.2 & 55.0 & 46.8 & 7.5 & 8.2 & 9.0 & 10.2 & 8.7 \\
\hline 80 & 40.2 & 45.2 & 59.9 & 61.6 & 51.5 & 8.1 & 9.0 & 10.2 & 11.8 & 9.8 \\
\hline 120 & 42.2 & 48.6 & 63.7 & 65.0 & 54.6 & 8.8 & 9.7 & 11.8 & 12.9 & 10.8 \\
\hline Mean & 38.8 & 43.9 & 55.6 & 58.0 & & 7.9 & 8.7 & 9.9 & 11.0 & \\
\hline
\end{tabular}

LSD (0.05) between treatment means

$\begin{array}{lll}\text { Shoot dry matter } & \mathbf{2 0 0 6} & \mathbf{2 0 0 7} \\ \text { Poultry manure }(\mathrm{P}) & 0.52 & 1.27 \\ \text { Potassium fertilizer (K) } & 0.52 & 1.27 \\ \text { P x K } & 1.04 & 2.54 \\ & & \\ \text { No. of corms/cormels } & & 0.32 \\ \text { Poultry manure (P) } & 0.29 & 0.32 \\ \text { Potassium fertilizer (K) } & 0.29 & 0.64 \\ \text { P x K } & 0.58 & \end{array}$

Table 5-Effect of poultry manure and potassium fertilizer on corms/cormels weight ( $\mathrm{kg}$ ) and corms / cormels yield (t/ha) of cocoyam in Uyo, Nigeria.

\begin{tabular}{|c|c|c|c|c|c|c|c|c|c|c|}
\hline \multirow{3}{*}{$\begin{array}{l}\text { Treatment } \\
\text { Potassium } \\
\text { (kg K/ha) }\end{array}$} & \multicolumn{5}{|c|}{ Poultry Manure (t/ha) } & & \multicolumn{4}{|c|}{ Poultry Manure (t/ha) } \\
\hline & 0 & 5 & 10 & 15 & Mean & 0 & 5 & 10 & 15 & Mean \\
\hline & \multicolumn{5}{|c|}{ Corms/cormels weight 2006} & \multicolumn{5}{|c|}{ Corms/cormels yield 2006} \\
\hline 0 & 0.04 & 0.05 & 0.06 & 0.07 & 0.06 & 2.8 & 3.5 & 4.9 & 5.8 & 4.3 \\
\hline 40 & 0.04 & 0.06 & 0.07 & 0.08 & 0.06 & 3.3 & 4.3 & 6.4 & 8.9 & 5.7 \\
\hline 80 & 0.05 & 0.06 & 0.09 & 0.10 & 0.08 & 3.8 & 5.8 & 10.6 & 13.0 & 8.3 \\
\hline 120 & 0.06 & 0.06 & 0.08 & 0.10 & 0.08 & 5.2 & 6.6 & 11.5 & 13.4 & 9.2 \\
\hline Mean & 0.05 & 0.06 & 0.08 & 0.09 & & 3.8 & 5.1 & 8.4 & 10.3 & \\
\hline $\begin{array}{l}\text { Potassium } \\
\text { (kg K/ha) }\end{array}$ & \multicolumn{5}{|c|}{2007} & \multicolumn{5}{|c|}{2007} \\
\hline 0 & 0.04 & 0.05 & 0.07 & 0.08 & 0.06 & 3.1 & 3.7 & 5.4 & 8.7 & 5.2 \\
\hline 40 & 0.04 & 0.06 & 0.08 & 0.09 & 0.07 & 3.8 & 4.5 & 6.8 & 10.2 & 6.3 \\
\hline 80 & 0.05 & 0.06 & 0.09 & 0.11 & 0.08 & 4.2 & 6.3 & 11.6 & 14.4 & 9.1 \\
\hline 120 & 0.06 & 0.06 & 0.08 & 0.11 & 0.08 & 5.7 & 6.9 & 12.7 & 14.6 & 10.0 \\
\hline Mean & 0.05 & 0.06 & 0.08 & 0.10 & & 4.2 & 5.4 & 9.1 & 12.0 & \\
\hline
\end{tabular}

LSD (0.05) between treatment means

$\begin{array}{lcc}\text { Corms/cormels weight } & 2006 & 2007 \\ \text { Poultry manure (P) } & 0.010 & 0.004 \\ \text { Potassium fertilizer (K) } & 0.010 & 0.004 \\ \text { P x K } & 0.020 & 0.008 \\ & & \\ \text { Corms/cormels yield } & 3.08 & 3.08 \\ \text { Poultry manure (P) } & 3.08 & 3.08 \\ \text { Potassium fertilizer (K) } & 6.16 & 6.16 \\ \text { P x K } & \end{array}$

